\title{
Intersectoral mobility of researchers in Russia: trends and policy measures
}

Irina Dezhina

Correspondence:

i.dezhina@skoltech.ru

Skolkovo Institute of Science and

Technology, 100 Novaya str.,

Skolkovo, Odintsovsky District,

143025 Moscow Region, Russia

\section{Springer}

\begin{abstract}
This article is devoted to analysis of researchers' internal mobility in Russia related to their movement between academic institutes or universities and industry - the so-called intersectoral mobility. Intersectoral mobility may acquire different forms: permanent, when a researcher moves from one organization to another for a full-time job, or temporary, as a part-time research work or consulting. Studies of internal mobility show a positive relationship between the level of intersectoral mobility and research productivity, which is the reason for a growing number of countries to introduce measures stimulating such movement of the research workforce.

In Russia, internal mobility of researchers is low and the government thus far has not paid much attention to this characteristic of labor resources. Mobility, as a knowledge transfer, is seen by the government mostly in terms of development of the science base in the government sector (research institutes and universities) but not as an instrument for fostering commercialization of research results. Such low mobility is rooted in Soviet legacy, including traditions as inbreeding, when universities persistently hire their own graduates.

An empirical part of the article describes results of the case studies conducted at an academic institute, a university, and state and private companies in order to assess the scale of and obstacles for intersectoral mobility in Russia and formulate potential government measures for stimulating this process.

Case studies confirmed the low level of intersectoral mobility but revealed that part-time research jobs are a commonplace. However, a typical form of such part-time occupation is for a professor to be employed by yet another research institute or university, which does not constitute intersectoral mobility. Suggestions of respondents were focused on measures aimed to promote mobility through strengthening linkages between industry and universities (research institutes). The proposed measures included joint work at shared research facilities and joint supervision of graduate and undergraduate students.
\end{abstract}

JEL classification: $\mathrm{O} 31, \mathrm{O} 32, \mathrm{O} 38$

Keywords: Internal mobility; Intersectoral mobility; Measures; Government policy; Russia 
Spanish: Movilidad intersectorial de investigadores en Rusia: tendencias y políticas

Resumen: Este artículo analiza la movilidad interna de investigadores en Rusia en lo que se refiere a su circulación entre institutos académicos o universidades y el sector empresarial (la así llamada "movilidad intersectorial"). La movilidad intersectorial puede adquirir formas diversas: permanente, cuando un investigador cambia de organización por un puesto de trabajo a jornada completa; o temporal, cuando se trata de un trabajo a jornada parcial o consultoría. Los estudios sobre movilidad interna muestran una relación positiva entre el nivel de movilidad intersectorial y la productividad en la investigación, que es la razón por la cual un número creciente de países introduce medidas de estímulo a la movilidad para los profesionales de la investigación. En Rusia, la movilidad interna de investigadores es baja y, hasta ahora, el gobierno no ha prestado mucha atención a este recurso laboral. La movilidad, al igual que la transferencia de conocimiento, es percibida por el gobierno como una forma de desarrollo de la base científica en el sector público (institutos de investigación y universidades), pero no como un instrumento para promover la comercialización de resultados de investigación. El bajo nivel de movilidad tiene sus raíces en el legado soviético, que incluye costumbres como la endogamia, que se da cuando las universidades continúan contratado a sus propios graduados. La sección empírica del artículo describe los resultados de los estudios de caso llevados a cabo por un instituto académico, una universidad y empresas estatales y privadas con el propósito de valorar el nivel y los obstáculos de la movilidad inter-sectorial en Rusia, así como formular medidas gubernamentales que estimulen el proceso.

Los estudios de caso confirman el bajo nivel de movilidad intersectorial, pero revelan que los puestos de trabajo a jornada parcila son habituales. Sin embargo, una forma común de este tipo de ocupaciones a jornada parcila consiste en que un profesor sea contratado por otro instituto de investigación o universidad, lo cual no supone movilidad intersectorial. Las sugerencias de los encuestados se centran en medidas que promuevan la movilidad mediante el fortalecimiento de los nexos entre el sector empresarial y las universidad (institutos de investigación). Las medidas propuestas incluyen trabajo conjunto en instalaciones de investigación compartidas y la supervisión conjunta de estudiantes universitarios y de posgrado. 
French: Mobilité intersectorielle des chercheurs en Russie: Tendances et Mesures Politiques

Résumé: L'article est consacré à l'analyse de la mobilité interne des chercheurs en Russie, en ce qui concerne les mouvements entre les instituts de recherche ou les universités et l'industrie - la dite "mobilité intersectorielle". La mobilité intersectorielle peut revêtir différentes formes: permanente, lorsqu'un chercheur change d'organisation dans le cadre d'un travail à plein temps; ou temporaire, dans le cas d'un travail de recherche ou de consultant à temps partiel. L'étude des mobilités internes montre une corrélation positive entre le niveau de mobilité intersectorielle et la productivité des chercheurs, ce qui explique pourquoi un nombre grandissant de pays ont pris des mesures pour stimuler la mobilité des personnels de la recherche. En Russie, la mobilité interne des chercheurs est faible et le gouvernement jusqu'à présent n'a pas encore vraiment porté attention à ce type de ressources professionnelles. La mobilité, à l'instar des transferts de connaissance, est vue par le gouvernement plutôt en termes de développement d'une base scientifique dans le secteur public (instituts de recherches et universités) plutôt que comme un instrument pour favoriser la commercialisation des résultats scientifiques. Cette faible mobilité est enracinée dans l'héritage soviétique, y compris dans les traditions d'endogamie, où les universités persistent à embaucher leurs propres diplômés.

La partie empirique de cet article décrit les résultats d'études de cas conduites dans un institut de recherche, une université, une entreprise publique et une entreprise privée afin d'évaluer le degré et les obstacles à la mobilité intersectorielle en Russie et de formuler des mesures politiques incitatives pour stimuler ce processus.

Les études de cas ont confirmé le faible niveau de mobilité intersectorielle, mais ont révélé par contre que les emplois de recherche à temps partiel sont monnaie courante. Une forme typique d'emploi à temps partiel est celle de professeurs employés par un autre institut de recherche ou une autre université, ce qui ne constitue pas une mobilité intersectorielle. Les mesures préconisées par les enquêtés visent principalement à promouvoir le renforcement des liens entre industrie et universités (instituts de recherche). Les mesures proposées incluent des facilités de travail conjointes dans des installations mutualisées et la supervision conjointe des étudiants diplômés ou de premier et de deuxième cycle. 
Chinese: 俄罗斯研究人员跨部门的流动性: 趋势和政策措施

摘 要: 这篇文章专门分析俄罗斯研究人员的内部流动性,即关于他们在学术机构 或大学和产业之间的移动 - 所谓 “跨部门流动性”。部门间的流动性可能获得 不同的形式: 永久性的, 当一个研究员从一个机构移动到另一个机构全职工作; 或 暂时的, 从事兼职的研究工作或咨询。内部流动的研究表明, 在部门间的流动性 的水平和研究生产力之间的正相关关系是越来越多的国家推出措施刺激研究劳 动力流动的原因。

在俄罗斯, 研究人员的内部流动性低, 政府迄今还没有非常重视劳动力资源的这

一特点。流动性, 作为一个知识转移, 被政府看作主要是就政府部门 (科研院所和 大学) 的科学基础的发展而言, 而不是被看作一种手段, 促进研究成果的商业

化。如此低水平的流动性根源于前苏联的遗产, 其中包括近亲繁殖的传统, 即大 学一贯聘用自己的毕业生。

本文的实证部分描述了对学术机构、大学和国有、私营公司的案例研究得出的 结果, 以评估俄罗斯跨部门流动性的规模和障碍, 制订可能的政府措施推动这一 进程。

案例研究证实了部门间的低水平流动性, 但发现兼职研究工作司空见惯。然 而, 这样的兼职职业的典型形式是教授被另一个研究机构或大学聘用, 不构成部 门间的流动性。受访者们的建议主要集中在采取措施通过加强产业和大学(科研 院所) 之间的联系促进流动性。所建议的措施包括在共享研究设施里进行合作研 究, 以及联合指导研究生和本科生。 
Russian: Межсекторальная мобильность ученых в России: тенденции и государственные меры

Аннотация: Настоящая статья посвящена анализу внутренней мобильности исследователей в России в контексте их перемещения между академическими институтами или университетами и промышленностью - так называемая «межсекторальная мобильность». Межсекторальная мобильность может принимать различные формы: постоянная, когда ученый переходит из одной организации в другую на условиях полной занятости; временная, в рамках которой занятость является неполной или осуществляется консультационная деятельность. В исследованиях, посвященных внутренней мобильности, подтверждена положительная связь между интенсивностью межсекторальной мобильности и результативностью исследований, что является предпосылкой к появлению во многих странах программ стимулирования таких переходов среди научных работников.

В России внутренняя мобильность исследователей низка, и руководство страны до настоящего времени не уделяло достаточного внимания данной характеристике человеческого капитала. Мобильность, равно как и трансфер знаний, рассматриваются правительством как способ развития научной базы в государственном секторе (исследовательские институты и университеты), а не в качестве самостоятельного инструмента, содействующего коммерциализации результатов исследований. Подобная низкая мобильность унаследована с советских времен; в частности, она основывается на традиции так называемого «научного инбридинга», когда университеты целенаправленно принимали на работу своих выпускников.

В экспериментальной части настоящей статьи представлен анализ деятельности академического института, университета, государственной и частной компаний, результаты которого позволяет получить данные о масштабах и барьерах на пути межсекторальной мобильности в России и определить потенциальные направления государственного стимулирования данного процесса.

Практические кейсы подтвердили низкий уровень межсекторальной мобильности; в то же время было обнаружено, что частичная занятость в исследовательской деятельности является обычным явлением. В свою очередь, подобная работа по совместительству присуща профессорам, которые могут работать в другом исследовательском институте или университете, что не является примером межсекторальной мобильности. Предложения респондентов содержали варианты стимулирования мобильности посредством упрочнения связей между промышленностью и университетами (исследовательскими институтами). Предложенные меры включали коллективную работу на общем исследовательском оборудовании и совместное руководство бакалаврами и магистрами. 
Portuguese: Mobilidade Intersetorial de Pesquisadores na Rússia: Tendências e Medidas Políticas

Resumo: Esse artigo é dedicado a análise da mobilidade interna de pesquisadores na Rússia, relacionados aos seus movimentos entre os institutos acadêmicos ou universidades e as empresas - chamada de "mobilidade intersetorial". A mobilidade intersetorial pode adquirir diferentes formas: permanente, quando o pesquisador muda de uma organização para outra em um emprego em período integral, ou temporário como um trabalho de pesquisa ou consultoria em tempo parcial. Estudos de mobilidade interna mostram a relação positiva entre o nível de mobilidade intersetorial e a produtividade das pesquisas, razão pela qual um numero crescente de países introduzirem medidas que visam estimular esse movimento de força de trabalho em pesquisa científica.

Na Rússia, a mobilidade interna de pesquisadores é pequena e governo até então não havia prestado muita atenção às características desses recursos de trabalho. A mobilidade, assim como a transferência tecnológica, é vista pelo governo principalmente em termos de desenvolvimento de base científica em setores governamentais (institutos de pesquisa e universidades), mas não como um instrumento para fomentar a comercialização dos resultados de pesquisas. Essa pequena mobilidade está enraizada no legado Soviético, incluindo tradições como a endogamia, quando as universidades persistentemente empregavam seus próprios graduados.

A parte empírica do trabalho descreve os resultados de estudos de caso conduzidos em um instituto de pesquisa, uma universidade, uma empresa pública e uma privada, a fim de avaliar o grau de mobilidade intersetorial e seus obstáculos na Rússia e sugerir potenciais medidas governamentais para estimular este processo.

Os estudos de caso confirmam o baixo nível de mobilidade intersetorial, mas revelam que empregos em pesquisas de tempo parcial são facilmente encontrados. No entanto, uma típica forma de ocupação em tempo parcial é para o professor que é contratado por outro instituto de pesquisa ou universidade, o que não constitui uma mobilidade intersetorial. Sugestões dos respondentes estão focadas em medidas destinadas a promover a mobilidade através do fortalecimento das relações entre empresas e universidades (institutos de pesquisa). As medidas propostas incluem um trabalho conjunto com instalações compartilhadas de pesquisa e supervisão conjunta de estudantes de graduação e pós-graduação.

\section{Multilingual abstract}

Please see Additional file 1 for translation of the Abstract into Arabic.

\section{Internal mobility: studies review}

Mobility studies are linked to human-capital theories. A human capital is a sum of an individual researcher's professional network ties, technical knowledge and skills (Bozeman and Corley 2004). Theoretical studies show a positive relationship between the human capital and innovative activity (Hoisl 2009; Guiri et al. 2007). A combination of different types of human capital is more likely to produce innovation than a mere increase in any particular type. Therefore, most works view mobility of researchers as a positive characteristic of labor resources.

Studies of internal mobility and its effects started at least 10 years ago, but a systemic view of this phenomenon and its influence on various characteristics of research activity is still missing. A number of empirical studies show that a more mobile 
researcher has a better record of publication and patent activity. However, some studies caution against overestimating the effects of mobility. The causal relationship between higher internal mobility and increased research productivity has not been proven yet; indeed, many other factors influence research productivity, including, for example, development of informal contacts between universities and companies and joint participation in scientific conferences (Cosh et al. 2005).

One of the most representative surveys of internal mobility was conducted in Denmark among personnel involved in research and development (R\&D) at 5,714 Danish firms (Ejsing et al. 2011). The data collected for 1999 to 2004 showed that university scientists hired by these firms generated more patents then the R\&D specialists hired from other companies. The workers, who stayed with the same company during the surveyed period, were the least productive in both absolute and relative terms. Additionally, the authors found that hiring university researchers and recent graduates is cheaper for the company than inviting specialists from R\&D divisions of other companies. And, thus, intersectoral mobility leads not only to productivity growth but also to financial savings.

The links between the mobility and publication output were studied using several countries (USA, Sweden, Spain, UK) as examples. The samples had different sizes and composition and, therefore, their direct comparison would be misleading. Nevertheless, these surveys yielded similar conclusions: mobile researchers (either moving within companies or moving to companies from outside) produce more publications than non-mobile researchers. For example, a survey among academic life scientists in USA has demonstrated that the mobile scientists (e.g., those involved in industrial consulting, postdoctoral residency with industry, etc.) produced twice as many publications as those having no interactions with industry (Zinner et al. 2009).

A survey in Sweden that involved analysis of CVs of 326 senior scientists, who were grant holders at the Swedish research foundation in 2002 to 2005 (Sandstrom 2009), revealed that, on average, these researchers changed their place of work twice. The most mobile researchers had the highest citation indices, whereas low-mobile and nonmobile researchers had low citations, and difference between these two groups was insignificant.

At the same time, the mobility effects differ depending on researchers' age (younger scholars are usually more mobile) and academic degrees (MA versus Ph.D.), as well as on the demand for researchers in different fields or disciplines. Additionally, the mobility is linked to recognition of a given researcher by the scientific community. "Star" scholars usually are less mobile since they have permanent positions, and the place where they work is associated, due to their scientific achievements, with "qualitative" science (Murray 2004).

In general, most scholars interpret mobility as a positive characteristic, and both business and public research organizations see internal mobility as a tool to obtain certain benefits. For public research organizations, these are economic advantages and intellectual input. For business, hiring researchers from universities and R\&D institutes leads to improvement of production and innovations. Still, in the relationship between the mobility and productivity, which of the two is the cause still remains unclear. In another words, there may be two opposite explanations: mobility leads to higher productivity or the most productive researchers become more mobile. 


\section{Intersectoral mobility in different countries}

Relatively few countries gather information about internal mobility of their researchers. The most detailed statistical data may be found in recent (2013) Organization for Economic Co-operation and Development (OECD) publications. The data collected for a 10-year period (2000 to 2009) in 25 countries demonstrated significant geographic variations of the mobility (Auriol et al. 2013). On average, 26.9\% of researchers changed their place of work during the surveyed period. The least mobile were researchers from Bulgaria, Belgium, Romania, and Russia, where less than $20 \%$ of researchers changed their place of work. These countries contrast with the most mobile country, the United States, where mobility was measured over the previous 2 years only but reached an average rate of $25.7 \%$, comparable with that of the other countries for which it was measured over a 10-year period, indicating a relatively higher rate of mobility over the decade.

Several years earlier, in 2010, European Commission conducted a sample survey of 4,537 university researchers working in EU-27 countries. The intrasectoral mobility in the form of changing jobs and moving either from one university to another or to research institutes appeared to be much higher than the intersectoral mobility with researchers moving from public research organizations to industry and vice versa. Sixty percent of researchers were involved in intrasectoral mobility while only $17 \%$ in intersectoral (Study on mobility patterns and career paths of EU researchers 2010). This study also showed that the level of mobility depends on discipline and occupation. The highest intersectoral mobility is among researchers in natural and technical sciences, the lowest in medical and agricultural sciences. In terms of occupation, the most mobile are postdoctoral researchers. The latter result appears to be natural since, in many countries, postdocs are forced to change their place of work every 4 to 6 years. The least mobile were graduate students, which is also explainable by their attachment to a certain school during their period of study (Figure 1).

The results of surveys conducted even during the same time periods differ significantly because of sample structures, as well as the somewhat vague definition of "intersectoral mobility", which may vary, for example, from any job change or to a part-time employment of university professors by industry.

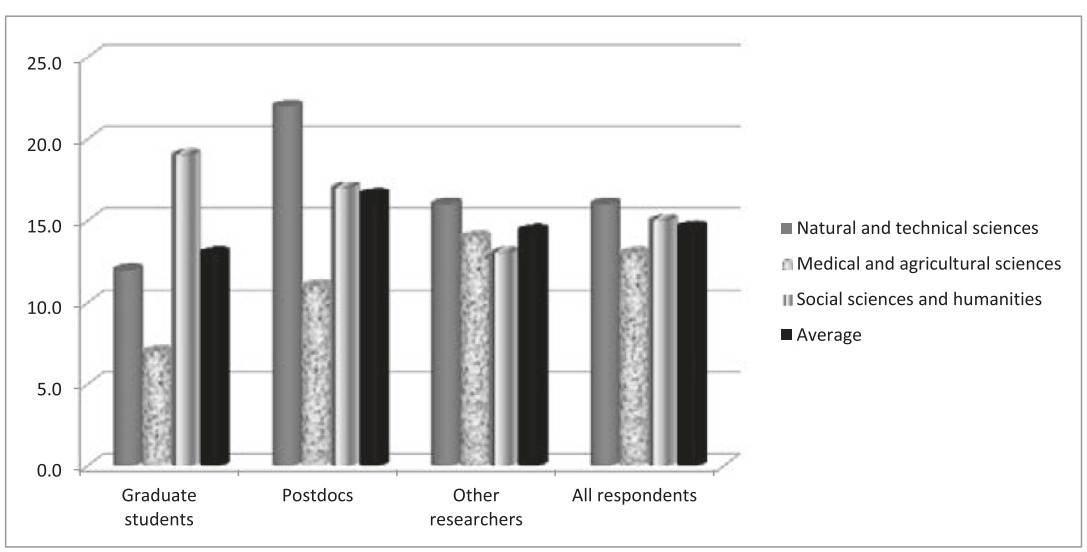

Figure 1 Share of university researchers in the EU-27 countries who have been employed as researchers. 
A separate set of studies is devoted to analysis of barriers, both economic and cultural (e.g., traditions, mentality) for intersectoral mobility. European studies of this topic are the most representative. Thus, for EU countries, critical barriers to mobility are the following (COM 2001):

1. Salary and pension schemes (possible loss of benefits after changing jobs),

2. Risk to lose the status of a civil servant (where it exists) or a professional status,

3. Differences in research culture between public research organizations and private companies,

4. Intellectual property rights and secrecy,

5. Absence of regulations in such areas as employment of professors by companies, joint supervision of undergraduate students, etc.

Among the factors mentioned above, intellectual property rights may be a real hamper for intersectoral mobility. In technologically developed Western countries, the problem of intellectual property initially was coming up primarily when a researcher left one private technology company and went to a competing private technology company, or when a researcher in a private technology company left and started his own technology company. Often companies required new employees to sign nondisclosure agreements but enforcing was difficult. Since the 1980s, the problem has become even more complicated - for example, in USA after the Bayh-Dole act permitted universities to transfer rights to industry. Potentially, mobility from universities can cause lawsuits. One of the consequences of these developments is large legal staffs in universities.

Some studies identify the absence of a positive link between the mobility and career growth as a barrier. Another factor, influencing mobility, is development of virtual forms of employment (virtual laboratories, outsourcing, crowdsourcing), which render physical mobility unnecessary. The term "crowdsourcing" was introduced in 2006, after the Internet became a routine tool. At first, this term was related to a search for business-decisions (Howe 2006). Crowdsourcing relates to creation of informal research groups, which independently solve the same research task. Crowdsourcing has led to appearance of a new type of researchers not linked to any organization. Its potential as a future form of research activity requires further studies (Bucheler and Sieg 2011).

\section{Internal mobility in Russia}

Until recently, the internal mobility of Russian researchers has not been studied. Russian scholars concentrated mostly on the exploration of external (international) mobility, which for Russia is better known as "brain drain". Such imbalance in studies of different types of mobility is explained by the fact that brain drain is a highly politicized topic. Studies of brain drain started in Russia in the beginning of the 1990s, when the most common view was that brain drain is a danger for the country since not only researchers leave but also with them - technical and technological know-how. Another popular direction of research was "the cost to train a researcher" and, thus, financial losses are caused by brain drain. Some discussants were even suggesting setting a price for every leaving researcher - analogous to a process of selling football players. 
However, despite the high level of attention to the problem of brain drain, there are no reliable quantitative data on its relative scale and evolution (Dezhina 2002).

Internal mobility in Russia was studied by few scholars, usually historians and sociologists. Quantitative assessments of internal mobility were made only once, by specialists from the National University - Higher School of Economics (NU-HSE) for the period 2000 to 2009 and later were used in various reviews, including those prepared by OECD. However, this (2000 to 2009) is a single set of data - data for later periods were not collected so far.

On the country scale, no information is collected that could highlight the state of internal mobility at least for doctorate holders. Thus, there is no data on where the Russian Ph.D. holders are employed and where they move. how many of them left science for another types of activity, and how many are officially jobless. Some information exists on movement of researchers between universities or from one government research institute to the other, i.e., about intrasectoral mobility. At the same time, the data on intersectoral mobility in form of movement from a university or a research institute to a company and vice versa is almost nonexistent. Different case studies indicate that, on average, the internal mobility of researchers in Russia is extremely low. Moreover, according to expert opinions, low mobility is among the critical factors that hamper innovations in Russia: a survey conducted by the Russian Venture Company in April 2013 indicates that the majority of expert respondents think that professional mobility is one of the least developed forms of knowledge transfer (Russia: focus on innovations 2013).

Besides the absence of official statistical data that could help in assessing the level of intersectoral mobility, there are other limitations to its study and interpretation. In Russia, in opposite to many other countries, a move from a university or a research institute to an industrial enterprise in many cases means not just a change of place of work but a change of profession because those entering industry often assume positions of managers, not researchers. Thus, such moves from universities to industry do not count as intersectoral mobility.

As mentioned earlier, the only existing assessment of internal, including intersectoral, mobility of researchers with the highest degree (in Russia these are candidate and doctorate degrees) was conducted by NU-HSE in 2010 (Shmatko 2011). The size of sample survey was 3,450 researchers ( $1 \%$ from all degree holders), working in all types of organizations in the Russian scientific complex. The survey has revealed that the majority of researchers (nearly $80 \%$ ) held the same job during the last 10 years. From those who did change job, $15.9 \%$ were researchers and $18.5 \%$ were university professors and other teaching staff. This level of intersectoral mobility is lower than that existing in most developed countries and countries with fast-growing economies. The study also revealed a high level of secondary employment not related to a job change. In most cases, secondary employment means combining research and teaching activity. Almost $60 \%$ of scholars working in research organizations said that they also teach at universities. At the same time, only $19.8 \%$ of candidate and doctorate degree holders combined their work at research institutes and universities with part-time employment in industry (not necessarily conducting R\&D there). Recent (2014) monitoring showed that only 3\% of researchers with candidate and doctorate degree plan to change jobs (without specifying whether it will be intrasectoral or intersectoral mobility) (NU-HSE 2014).

Another article from NU-HSE (Altbakh et al. 2012) analyzes systems of salaries and bonuses for professors and shows that in Russia, about 22\% of professors are employed 
by more than one university due to the low average salary of professors. Secondary employment is usually connected to an additional educational, and not research, activity.

The low percentage of teaching staff at Russian universities which is involved in research is a well-documented fact. At the end of the 2000s, this number was estimated as $20 \%$ (Roshina and Yudkevich 2009). Latest studies of publication activity in leading Russian universities show that less than $10 \%$ of teaching staff publishes in international journals (Arefyev 2014). Since research activity at Russian universities is low, it is difficult to expect a high level of intersectoral mobility of teachers and researchers.

For Russia, an important and specific factor hampering intersectoral mobility is related to practices of hiring and promoting the teaching and research staff. Even though there is no tenure in Russian universities and all positions are open for competition, de facto, a position of an assistant professor or a professor is a permanent one, due to procedure of professional attestation. In this procedure, the level of involvement of a professor in research had low importance and the contracts typically did not specify which results should be achieved in research activities of professors and assistant professors. The level of research performance was not influencing career development and, thus, such practice does not create environment for mobility.

Even a more serious obstacle is the practice of inbreeding, when universities fill positions of assistant professors and professors preferentially with their own graduates. About $2 / 3$ of teaching staff at Russian universities are working at the universities from which they graduated (Sivak and Yudkevich 2009). Moreover, 62\% of department chairs think that this practice should be continued and only $15 \%$ are ready to attract specialists from industry. In fact, these practices not only present an obstacle to the internal mobility but also contribute to stagnation in research since the quality of personnel becomes a secondary factor.

The specifics of mentality are also in moral and emotional attachment of employees to their universities, not to profession. This decreases the level of internal mobility even between universities both during initial and later stages of academic career (Yudkevich 2013).

This mentality reflected in hiring of own graduates is typical not only for universities but also for the academy research institutes. In the academy, leaving an institute is often seen as a betrayal of the organization, making a return difficult, if possible at all. This practice may be rooted in the elite position of academy in Soviet Union. These institutes had better access to equipment and foreign literature, and their scientists enjoyed more academic freedom. Leaving such "elite corporations" meant certain unreliability and rejection of the system. There was an influence of "old boys" networks in science, including those that were considered as "scientific schools". Academy scientific schools represented small groups united around their leaders and are often hostile to newcomers (Rodnyi 2010).

\section{Government regulation: western experience}

Western countries in recent years started to pay more attention to internal mobility that has led to introduction of new measures to stimulate it, including intersectoral one. As it was stated in the "New Concepts of Researcher Mobility" issued in April 2013 by European Science Foundation, "mobility is not a goal in itself, but rather a means for research collaborations across fields and sectors". 
Foreign experience shows that there are no universal measures that would be fully productive to stimulate internal mobility. However, some of them were successfully adopted in different countries. For example, part-time research positions (so-called Norwegian 'Professor 2') were adopted in Germany and USA (at Harvard University and MIT). Part-time/combined positions were introduced at universities for industry specialists. Such specialists may spend $20 \%$ of their time working at universities as an add-on to their main positions, financed by either party. These positions have flexible regulations because they may be permanent or time-limited (for several years), by personal invitation or through open calls. A second widespread type of measure is parttime or temporary positions in industry for academic scientists. For companies, hiring academic researchers is cheaper than hiring specialists from other firms.

Historically, stimulation of internal mobility was moving from direct to indirect measures. This may be illustrated based on the example of the USA where the government started to pay attention to internal and intersectoral mobility earlier than their counterparts in Western Europe.

Implementation of direct measures in the USA started in the end of the 1980s through the National Science Foundation (NSF). It initiated the program called GOALI Grant Opportunities for Academic Liaison with Industry. The program consists of three components, and two of them are directly linked to mobility:

- Grants for teaching staff, postdocs, and students to conduct research in industry;

- Grants for scientists and engineers from industry to work at universities;

- Grants for interdisciplinary research conducted by groups that include representatives of universities and industry.

The level of funding was rather modest and so these grants were intended to play mostly a stimulating role. The major goal was to bring closer university professors and industrial researchers and to encourage them to exchange personnel, which in turn should have inspired long-term collaborations. The program was very flexible because there were very few predetermined conditions. Thus, participating companies were not limited by size and possible forms of collaboration. Examples of exchanges supported through GOALI are the following:

- Part-time work of an industry scientist at a university;

- Temporary work (for semester or two) of undergraduate or graduate students at a company as a part of their thesis;

- A postdoc position at a company for 1 to 2 years under the guidance of a university professor;

- Research work of university professors at companies or teaching there.

In fact, the GOALI program was born out of certain problems with implementing public-private partnerships. The experience showed that for successful collaboration between universities and industry, mutual understanding is crucial (Hodges 2011). In gaining such understanding, an experience in working in both academic and private sectors plays an important role. Later, programs similar to GOALI were initiated by the Department of Commerce and the Department of Energy. 
More recently, for stimulation of internal mobility, instruments aimed at cooperation between universities and industry were applied (e.g., SBIR program, Engineering Research Centers program, and many others). Studies of mobility effects in the USA have revealed that there is a positive connection between the mobility and research productivity, as measured using bibliometric indicators and patent data.

At present, the conditions for development of business activity in the USA are much more beneficial than that in Russia (Table 1), which facilitates intersectoral mobility.

The quality of government regulations and the rule of law are also strong features of the American economy. The private sector in the USA actively invests in R\&D, and, therefore, there are many $R \& D$ divisions in industry with job opportunities for scientists working in other sectors. Another indicator of favorable conditions for the intersectoral mobility in the USA is the high level of technology absorption at companies and the developed cooperation between universities and industry. Finally, characteristics of labor resources show that it is relatively easy to hire personnel in the USA, in contrast to Russia that lacks high-class professionals.

At present, intersectoral mobility attracts a growing attention in the USA. In part, this interest can be explained by a change in attitude toward this problem in Western Europe. EU countries have been paying attention to intersectoral mobility since the beginning of the 2010s. Recent expert reviews and government reports indicate importance of mobility. For example, the report "Arise 2: Unleashing America's Research and Innovation Enterprise" (Arise 2013) emphasizes the importance of training specialists that can work in both systems - universities and companies. In order to train such professionals, government should support exchange programs. Currently, these exchanges are well developed at the level of particular organizations but not as an activity specifically encouraged by the US government.

\section{Government initiatives in Russia}

In Russia, internal mobility of researchers was not considered an issue at the government level. The country as a whole is fairly immobile, especially geographically, which is inherited from the Soviet period. There are very few places of attraction for labor

Table 1 Comparison between USA and Russia by a number of indicators reflecting conditions and results of research and innovative activity

\begin{tabular}{lll}
\hline Indicators & USA & Russia \\
\hline Number of days to start business, 2011 & 6 & 30 \\
Quality of government regulations (expert evaluation), 2009 & 1.36 & -0.46 \\
Rule of law (expert evaluation), 2009 & 1.53 & -0.77 \\
Level of cooperation between universities and companies & 5.80 & 3.70 \\
(measured from 1 to 7), 2010 & 3.80 & 2.30 \\
Availability of venture capital (measured from 1 to 7), 2010 & 5.40 & 3.20 \\
Expenditures of private sector on R\&D (measured from 1 to 7), 2010 & 6.00 & 4.00 \\
Technology absorption at firm level (measured from 1 to 7), 2010 & 29.78 & 40.73 \\
Share of articles with international co-authorship (\%), 2008 & 5.88 \\
Level of unemployment (\% to labor resources), 2005 to 2009 & 0.00 & 33.00 \\
Complications in hiring personnel, 2010
\end{tabular}

Source: based on the World Bank Knowledge Economy Index. http://web.worldbank.org/WBSITE/EXTERNAL/WBI/ WBIPROGRAMS/KFDLP/EXTUNIKAM/0,,menuPK:1414738 pagePK:64168427 piPK:641684351theSiePK:141472,00.html 
resources and even less so for doing research. Most of the research potential and best research institutes are located in and near Moscow and St. Petersburg as well as in Novosibirsk Academic Town. The latter hosts mostly an academic sector of science, whereas high-tech industry is insignificant. Therefore, intersectoral mobility could be the most developed in "two capitals" - Moscow and St. Petersburg; however it never was encouraged by the government. And Russian research complex, being mostly government-owned and government-regulated, is very attentive to government signals. As a result, very few initiatives can be mentioned, which include encouragements of internal (intersectoral) mobility as a component of a complex measure.

The following government initiatives lightly touch the problem of internal mobility:

1. Support of consulting services and exchanges within the program of creation of innovative infrastructure in Russian universities (started in April 2010).

2. Sub-program "youth mobility" within federal goal-oriented program "Scientific and scientific-pedagogical potential of innovative Russia for 2009 to 2013" (terminated).

3. One of the initiatives of the Russian Foundation for Basic Research, called "mobility of young scientists" (terminated).

4. Establishment of laboratories at Russian universities and academy institutes chaired by the world's leading scientists (started in April 2010).

Not only measures were scarce and in most cases short-term but also evaluation of outcomes is difficult because no data on mobility were collected. Therefore, only indirect information can be used to understand the nature of mobility and the extent to which it was encouraged by the government measures.

The results of support of consulting services and exchanges show that $47(60 \%)$ out of 78 universities, which participated in this program, were interested in consulting. The subjects in demand were training of personnel and various aspects of creating small innovative enterprises. Whether the consulting stimulated closer linkages between universities and companies is unknown. However, given that only five universities were interested in in-country exchanges and there were only two companies among the partners, such linkages appear to be insignificant. Additionally, most of the exchanges were between the universities. This confirms an earlier observation that in Russia, some internal mobility occurs within the government sector of science, whereas intersectoral mobility is nearly nonexistent.

Two other programs (already terminated) related to stimulating the mobility of young scientists also provide scarce information on the subject. The data exists regarding the number of grantees and the level of competition. The latter was low which suggests that young scientists were not very interested in temporary work (according to calls for proposals - up to 6 months) in other organizations, especially if these workplaces were located in another region.

The recent program aimed at establishment of modern laboratories in Russian universities and research institutes potentially could also stimulate mobility, even though enhancing mobility is not among the primary goals of this initiative. Research groups at the newly created laboratories are expected to be more mobile naturally, and their ties with international researchers could turn these laboratories into centers of networking within Russia further stimulating mobility. However, so far, these laboratories helped to reveal several factors that may complicate mobility rather than stimulate it. 
First, insufficient qualifications of researchers and technical personnel working in a number of research directions hamper intersectoral mobility. Second, it is low mobility of labor resources which hampers creation of temporary research groups that may work in/with the laboratory. Here, an additional hampering factor was an unclear future of this initiative as a whole. The government promised the support for 3 years only, with possible but unguaranteed extension for another 2 years. In practice, out of the first group of laboratories established in 2010, 60\% received a continued support after 3 years. New laboratories, created in 2012 to 2013, had to deal with the already changed government requirements, which required the laboratories to guarantee a $25 \%$ cofinancing from non-budgetary sources. In practice, universities and research institutes paid this share from their own funds; therefore, the new requirement has not achieved its goal of enhancing ties with industry.

For 2015, the new Russian Science Foundation, which has been established in 2013 and is now the largest government funding body, announced about its plans to stimulate internal mobility through special programs. Russian Science Foundation decided to focus on the geographic mobility of scientists. The first program will support projects chaired by either Russian or foreign scholars. Foreign scientists should be present in Russia for at least 183 days (to be considered residents for tax purposes). Both Russian and foreign scholars may only chair those laboratories that were created outside Moscow or St. Petersburg. The general idea behind these regulations is to promote science in Russian province due to influx of high-level researchers from the Russian capitals and from abroad. The Foundations' leadership plans to grant 50 to 100 awards anticipating some level of competition.

The second program is for postdoctoral positions. The requirement will be not only to change a place of work (to leave an organization where the thesis was defended) but also to move to another region within Russia. In our view, taking into account a geographic distribution of science in Russia, the focus on geographic mobility is not justified since there are not enough research centers of sufficiently high level outside the capitals.

Analysis of the government approaches to internal mobility suggests that stimulating intersectoral mobility is not among the government priorities; instead, it is supported rather indirectly, within initiatives having different goals. New measures toward some forms of internal mobility, such as the geographic one, may actually temporarily increase it; such measures will mostly be directed toward the government and university sectors of science and therefore do little to change linkages between science and industry.

\section{Case studies: internal mobility in Russia, obstacles and prospects}

In order to bring more light to the current state of intersectoral mobility in Russia and identify government measures that may fit best to promote it taking into account the Soviet legacy, case studies were conducted at different types of research organizations: a university, an academy institute, and state and private companies. All the organizations are located in Moscow which could influence the results of the study (presumably Muscovites have more possibilities for intersectoral mobility because many companies that have R\&D divisions and are interested in promoting research are located in the 
region). Respondents were researchers at the middle administrative level (heads of divisions, department chairs, heads of laboratories). The survey was conducted in 2013 to early 2014, before the Russian Science Foundation has developed its own approaches to encourage mobility. The survey was based on in-depth unfocused interviews. The respondents were selected based on the "snowball" method; a total of 25 professionals were contacted, and 14 agreed to take part in the interviews.

The major research questions were as follows: what is the level of intersectoral mobility, what are the hampering factors, and what can be done to make labor resources in science more mobile?

The underlying hypotheses were as follows:

1. The level of intersectoral mobility is low in both directions - from universities and academy institutes to industry and vice versa.

2. The major reasons for low mobility are historical traditions in hiring research personnel at universities and academy institutes (inbreeding) as well as low levels of industrial investments in R\&D and thus insignificant interest in knowledge transfer from universities and academy. Finally, a hampering factor can be a level of qualification of scientists in terms of ability to cooperate with industry and consult companies in an R\&D area.

3. Foreign practices of government regulation are not well suited for Russia since most of them are based on analysis of science and industry; they, therefore, are imbedded in measures aimed at stimulating interactions between science and industry. In Russia, on the other hand, the government prefers direct financial support of $R \& D$; therefore, there is no cultural tradition of applying measures that indirectly stimulate linkages among actors in the innovation system.

\section{Findings: level of mobility and major obstacles}

All respondents expressed a solid opinion that internal and intersectoral mobility is useful for knowledge transfer and improving quality of workforce. A respondent from the academy institute made the following comment:

"There is a clear usefulness from double employment in an Academy institute and an industrial company. A career in the Academy gives a broad view - something, lacking in companies....Usefulness for Academy - better understanding of real demand, of how it is in real life".

A similar view was expressed by the university professor:

"Mobility gives broad thinking, and in final analysis it speeds up industrial development. The most mobile should be researchers from industry and from technical universities. It intensifies patent productivity".

All respondents without exclusion admitted that Russia is not a mobile country. At the same time, representatives of a private company stated that, for them, it is not a problem. If they need a certain professional, they "buy" him or her. Moreover, there are special 
positions that presuppose frequent changes in location, including geographic mobility. However, part-time employment is common while mobility is not:

"We do not have mobility, we have "presence" in several places. For Russia mobility is unnatural".

Respondents indentified several factors of low mobility. The first one is a mentality of administration, such as directors of institutes and rectors of universities. Employees are seen as a part of an "empire" and, thus, changing jobs is unwelcome:

"In our companies there are not many part-time workers; company wants to have everybody full-time" (a company representative)

"Companies could be interested to employ academics part-time; however, leadership of academic institutes leadership is against this practice. In companies, salaries are higher and therefore sooner or later a part-time position leads to a full job. There is no "intermediate" option, when it would be possible to combine work in academy and industry" (a company representative)

The second factor is low quality of researchers employed in the government sector of science. Respondents see it as a serious obstacle to intersectoral mobility:

"In university $N$, the result of teaching is that $90 \%$ of graduates are unskilled. In other universities it is also difficult to find graduates able to work under contracts from industry" (a private company representative also is working part-time as university professor)

"Nobody expects from professors and other teaching staff an ability to do good research project. Contacts with universities are mostly seen as a way to find qualified graduates" (a private company representative)

The third reason is aging of researchers in the government sector and universities. An average age is growing and older people are less mobile:

"...mobility is low - both geographic and institutional. In academic institutes most of the actively working scientists are old, and it is difficult for them to move anywhere" (an Academy institute representative)

"... at the beginning of 2000s, the situation with workforce was much better, including the one in universities. Now there is nobody to work with. The level of RED is declining. There are the same people in place who were 10-20 years ago. There are no middle-aged researchers, and younger ones are leaving sooner or later. There are some points of increase but there are too few of them" (a private company representative)

The fourth reason, mentioned only by a single respondent, is stagnation in industry: 
"We do not have a long-term high-tech business with regular investments in RED. Therefore, companies are not interested in promoting research mobility. A policy related to labor resources is important only if there is a forecast for development at least until 2020" (a private company representative)

\section{Findings: measures to stimulate mobility}

The respondents were asked about possible measures that the government should put in place to stimulate intersectoral mobility. In order to help the respondents to answer this question, a general description of policy measures implemented abroad was presented. Based on the foreign experience and the current situation in Russia, the respondents expressed their opinions regarding the government policy.

One possible activity for the government is encouragement of cooperation between universities, academy, and companies within centers of shared research facilities. Such centers were created with federal support in many universities and research institutes. Cooperation may lead to joint research projects and their commercialization. The centers may become the bases for researchers' exchanges.

The second direction is to promote mobility through work with students (both undergraduate and graduate) supervised jointly by a professor and an industry representative. The respondents from private companies did not see obstacles to this type of cooperation. The state company representative thought that government-controlled industry is too regulated, leaving no room for careful work with students. Nevertheless, despite some difficulties, this direction was recognized as very promising.

The third direction involves attracting retired researchers, who formerly worked for industry, to serve as consultants at universities, thereby transferring their knowledge and helping to develop linkages between universities and companies.

The fourth direction is related to regulatory measures. It was suggested that one of performance indicators for universities should be the level of their cooperation with companies:

"It is necessary to suggest system of indicators for universities showing how they work with industry. There should not be solid quantitative numbers that universities should achieve - like number of joint projects or number of consulting agreements. Rather, it is better to concentrate efforts on development of collaborative schemes, their pilot approbation and implementation of the most successful practices" (a state company representative)

\section{Discussion and policy implications}

The case studies confirmed the first two hypotheses - the low intersectoral mobility and the list of major obstacles to it. In fact, the list of obstacles turned to be even broader than initially expected. As an important obstacle, the respondents mentioned that, in the Russian science, there are many old researchers who are not mobile "by definition", i.e., because of their age. It should be also underlined that with even representatives of Moscow organizations being pessimistic about the level of internal mobility, the situations in regions are likely to be even worse.

The third hypothesis regarding possible government measures was not fully justified. Most measures suggested by the respondents were intended to promote mobility 
through various ways to establish and strengthen linkages between industry and universities (research institutes). The first steps for changing the situation might be related to joint work at shared research facilities and joint supervision of graduate and undergraduate students.

The results of the survey also suggest additional policy measures that take into account the Russian situation: availability of a large number of older (retired) researchers, whose experience can be used to strengthen channels of knowledge transfer, and the specificity of the government-regulated R\&D sector in Russia, in which all the organizations report to the government about their achievements using certain metrics (sets of indicators). Including the indicators of intersectoral mobility as measures of success could make intersectoral mobility more intensive and thus productive.

Meanwhile, the government stays fairly passive in promoting internal and, especially, intersectoral mobility. Several types of measures stimulating it indirectly started 5 years ago but recently most of them were terminated. Instead, several new activities are likely to be initiated with a focus on geographic mobility. Therefore, mobility as an instrument of knowledge transfer is seen mostly in terms of development of the science base in the government sector (research institutes and universities) but not as a way to foster commercialization of research results. The government approach could be more diverse and productive, if government agencies would consider several additional measures, such as stimulating mobility through part-time work of students in companies, joint projects conducted in small innovative companies, and wider introduction of postdoc positions without a requirement to relocate to another region.

\section{Additional file}

Additional file 1: Translation of the abstract into Arabic.

Received: 19 January 2015 Accepted: 21 April 2015

Published online: 06 May 2015

\section{References}

Arefyev P (2014) International publication activity of leading Russian universities in 2013. Paris Part 1., http:// www.unkniga.ru/vishee/3588-mezhdunarodnaya-publikatsionnaya-aktivnost-veduschih-rossiyskih-universitetov-v2013.html Accessed 18 December 2014 (in Russian)

Arise 2: Unleashing America's Research \& Innovation Enterprise (2013). American Academy of Arts and Sciences. http:// www.amacad.org/multimedia/pdfs/publications/researchpapersmonographs/arise2.pdf Accessed 4 January 2015

Auriol L., Misu M. \& R.A.Freeman. (2013) Careers of doctorate holders: analysis of labor market and mobility indicators. OECD science, Technology and Industry Working Papers, Paris 2013/04, OECD Publishing.

Bozeman B, Corley E (2004) Scientists' collaboration strategies: implications for scientific and technical human capital. Res Pol 33:599-616

Bucheler T, Sieg J (2011) Understanding science 2.0: crowdsourcing and open innovation in the scientific method. Procedia Compu Sci 7:327-9

COM (2001) 331 Final of 20.6.2001. A mobility strategy for the European research area

Cosh A., Hughes A. \& Lester R. (2005) UK PLC: just how innovative are we? Cambridge MIT Institute.

Dezhina I (2002) "Brain drain" from post-Soviet Russia: evolution of the phenomenon and is assessments. Naukovedenie 3:37-9 (in Russian)

Ejsing A-K., Kaiser U. \& Kongsted H.C. (2011) Unrevealing the role of public researcher mobility for industrial innovation, IZA Working Papers. IZA Discussion paper, n. 5691, May.

Guiri P., Mariani M., Brusoni S., Crespi G., Francoz D., Gambardella A., Garcia-Fontez W., Geuna A., Gonzales P., Harhoff D. Hoisl K., Le Bas C., Luzzi A., Magazzini L., nesta L., Nomaler O., Palomeras N., Patel P., Romanelli M., Verspagen B. (2007) Inventors and Invention Process in Europe: Results from the PatVal-EU Survey. Research policy, vol.36, issue 8. pp. 1107-1127.

Hodges D (2011) Industry-university cooperation, and the emergence of start-up companies. P.2., http://www.rieti.go.jp/ en/events/01121101/Hodges_final.pdf Accessed 4 January 2015

Hoisl K (2009) Does mobility increase the productivity of inventors? J Tech Tran 34:212-25

Howe J (2006) The rise of crowdsourcing. Wired Magazine 14(6):1-4 
How professors are paid? Global comparison of the systems of payments and contracts. Eds. Altbakh F., Raisberg L., Yudkevich M., Andrushak G., Pacheko I. Monograph. Moscow: ID HSE, 2012. (in Rusian)

Murray F (2004) The role of academic inventors in entrepreneurial firms: sharing the laboratory life. Res Pol 33:643-59 National Research University - Higher School of Economics monitoring of research workforce with higher degrees

(2014) http://issek.hse.ru/news/140299836.html?utm_source=getresponse\&utm_medium=email\&utm_ campaign=issek_rus\&utm_content=\%D0\%9D\%D0\%BE\%D0\%B2\%D0\%BE\%D1\%81\%D1\%82\%D0\%B8 +\%D0\%98\%D0\%A1\%D0\%98\%D0\%AD\%D0\%97+\%D0\%9D\%D0\%98\%D0\%A3+\%D0\%92\%D0\%A8\%D0\%AD\%2C +\%E2\%84\%96+6\%2C+2014 Accessed 4 January 2015 (in Russian)

Rodnyi A (2010) Mobility in science. Sotsiologiya nauki I technologii 2:76-88, http://cyberleninka.ru/article/n/ professionalnoe-prostranstvo-institutsionalnoy-mobilnosti-uchenyh Accessed 11 November 2014 (in Russian)

Russia: focus on innovations (2013). Open expert-analytical report about pace of development "Strategy of innovative development of the Russian Federation till the period 2020". Vol. 1. Moscow: OAO "RVK" (in Russian).

Ya R, Yudkevich M (2009) Factors of research activity of university teachers: politics of administration, contractual incompleteness or influence of environment? Voprosy obrazovaniya 3:203-28 (in Russian)

Sandstrom U (2009) Combining curriculum vitae and bibliometric analysis: mobility, gender and research performance. Res Eval 18(2):135-42

Sivak E, Yudkevich M (2009) Academic inbreeding: pro and contra. Voprosy obrazovaniya 1:170-87 (in Russian)

Shmatko N (2011) Scientific capital as a driver of social mobility of researchers. Foresight 5(3):18-32 (in Russian)

Study on mobility patterns and career paths of EU researchers (2010) Technical report 2 - part I: mobility survey of the Higher Education Sector. IDEA Consult, Brussels

Yudkevich M. (2013) Russian academic profession and creation of world class universities]. Otechestvennye zapiski, n. 4. http://www.strana-oz.ru/2013/4/rossiyskaya-akademicheskaya-professiya-i-postroenie-peredovyhuniversitetov?fb_action_ids=10151805976492769\&fb_action_types=og.recommends\&fb_source=hovercard Accessed 19 April 2014 (in Russian)

Zinner D, Bjankovic D, Clarridge B, Blumenthal D, Campbell EG (2009) Participation of academic scientists in relationships with industry. Health Aff 28(6):1037-9

\section{Submit your manuscript to a SpringerOpen ${ }^{\circ}$ journal and benefit from:}

- Convenient online submission

Rigorous peer review

- Immediate publication on acceptance

- Open access: articles freely available online

- High visibility within the field

- Retaining the copyright to your article 